\title{
Assessment of the Water Quality of the Radika River in the National Park Mavrovo in the Republic of Macedonia
}

\author{
Kole Pavlov $^{1 *}$, Radmila Bojkovska ${ }^{2}$, Gjorgi Pavlovski ${ }^{3}$ \\ ${ }^{\mathbf{1}}$ Josip Broz Tito High School/University of Tourism and Management, Skopje, Republic of Macedonia \\ ${ }^{2}$ National Hydrometeorological Service, Skopje, Republic of Macedonia \\ ${ }^{3}$ University of Goce Delcev, Stip, Republic of Macedonia \\ *kolepavlov@yahoo.com
}

\begin{abstract}
The drainage basin of the Radika River is located in the western parts of the Republic of Macedonia and almost entirely belongs to the national park Mavrovo, which is also a treasury of geomorphologic, biological and cultural heritage. Waste water from households, catering facilities, as well as the developed economic activities in the fields of agriculture, cattle breeding and large tourist saturation are sufficient factors that would violate the quality of the Radika River, which is considered to be a protected and clean watercourse in the region, and wider in the country. According to the legal regulations in the Republic of Macedonia, the waters of Radika River in the national park Mavrovo shows solid summarized quality. Detected quality anomalies primarily express the organic burden as an anthropogenic source of pollution. The natural factors on the other hand, are not a major hazard to the aquatic ecosystem.
\end{abstract}

Keywords: Radika; Measuring Point; Pollution; Heavy Metals

\section{INTRODUCTION}

The catchment area of the Radika River covers $3.4 \%$ of the territory of the Republic of Macedonia [1]. It is also a protected zone and almost entirely belongs to the largest national park, Mavrovo, which covers 73,088 hectares. The majority of natural and cultural objects in the national park as tourist motives contributed to the existing accommodation capacities annually staying over 35,000 tourists who accomplished over 160,000 overnight stays [2]. The domicile population and the various types of tourism in the basin are a sufficient symptom of possible pollution of the waters of the Radika River as the main recipient of surface waters that from a legal perspective, for a protected area, must stay within quality class I-II. For these reasons, the need for a studious study of the water quality of the Radika River spontaneously was imposed on the move in the national park Mavrovo whose waters can be used for a number of purposes. Subject of study in this paper were the waters of the Radika River which were monitored in the lower, southern part of the basin at the place known as Boskov Most (sample point, Fig. 1). The assessment of the water quality of the Radika River was based on 10 parameters from the basic physical and chemical analysis, 4 alkaline metal cations and 6 heavy metals as a quality criterion. The purpose of the labor is to systematically detect the current quality, contamination with heavy metals in the watercourse, connection with the water regime (flow), as well as to identify natural and anthropogenic sources of pollution in order to propose the most adequate measures for protection against pollution and promotion the quality of water.

\section{STUDYAREA}

The drainage basin of the Radika River is located in the western parts of the Republic of Macedonia (Fig. 2). It is confined with high mountains: Sharr Mountain from the north, Bistra from the east, Stogovo from the south, Korab and Deshat from the west. Within this framework, the drainage of the Radika River covers $880 \mathrm{~km}^{2}$, or $3.4 \%$ of the territory of the Republic of Macedonia. The geological composition is dominated by Paleozoic shales, Jurassic limestones and flish series from the Cretaceous. The length of the Radika River is $67 \mathrm{~km}$. It springs at 2200 meters and flows into the Debar Lake at 587 meters. The mean elevation of the basin is 1,554 meters [1]. The total fall of the river flow is 1773 meters, and the average drop is $27.3 \%$. About $19.5 \%$ of the drainage basins are karstificated, and forests cover over $35 \%$ of it. The annual amount of precipitation in the basin is $1063 \mathrm{~mm} / \mathrm{m}^{2}$. The average annual water flow (Q) at the Boskov Most control point is $18,87 \mathrm{~m}^{3} / \mathrm{s}$ (Fig. 3). The smallest flow occurs in the months of August and September, and the largest in April and May. The specific drainage from the basin (q) is $22.7 \mathrm{l} / \mathrm{s} / \mathrm{km}^{2}$. 


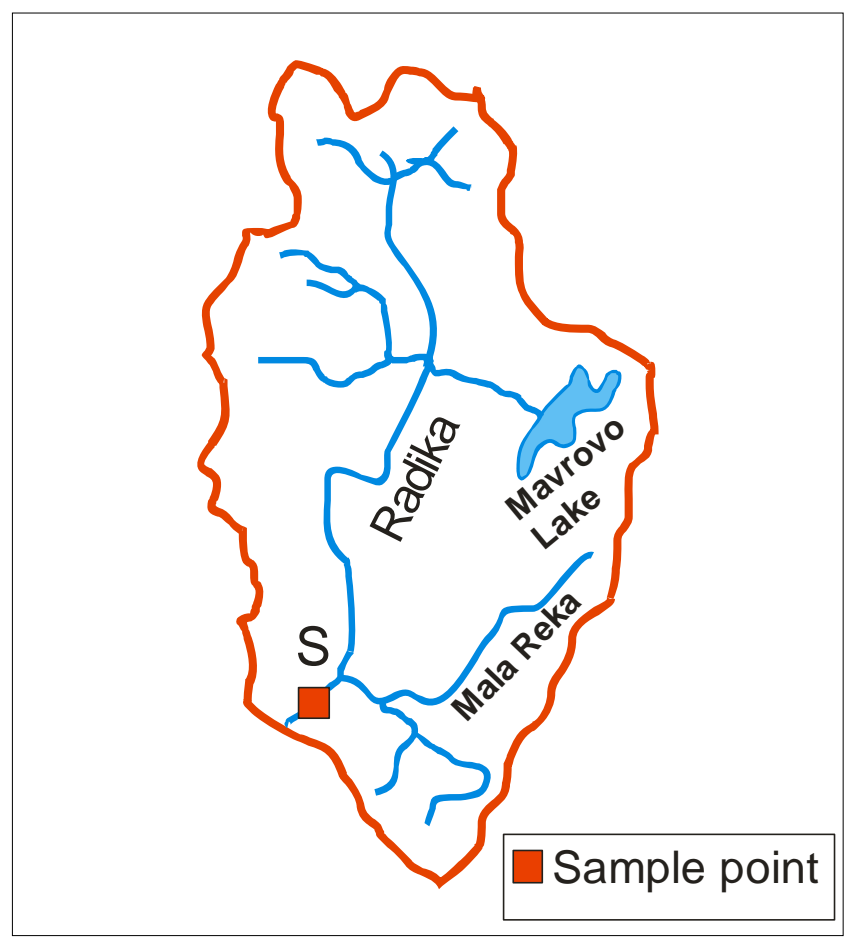

Fig. 1 The drainage basin of Radika River

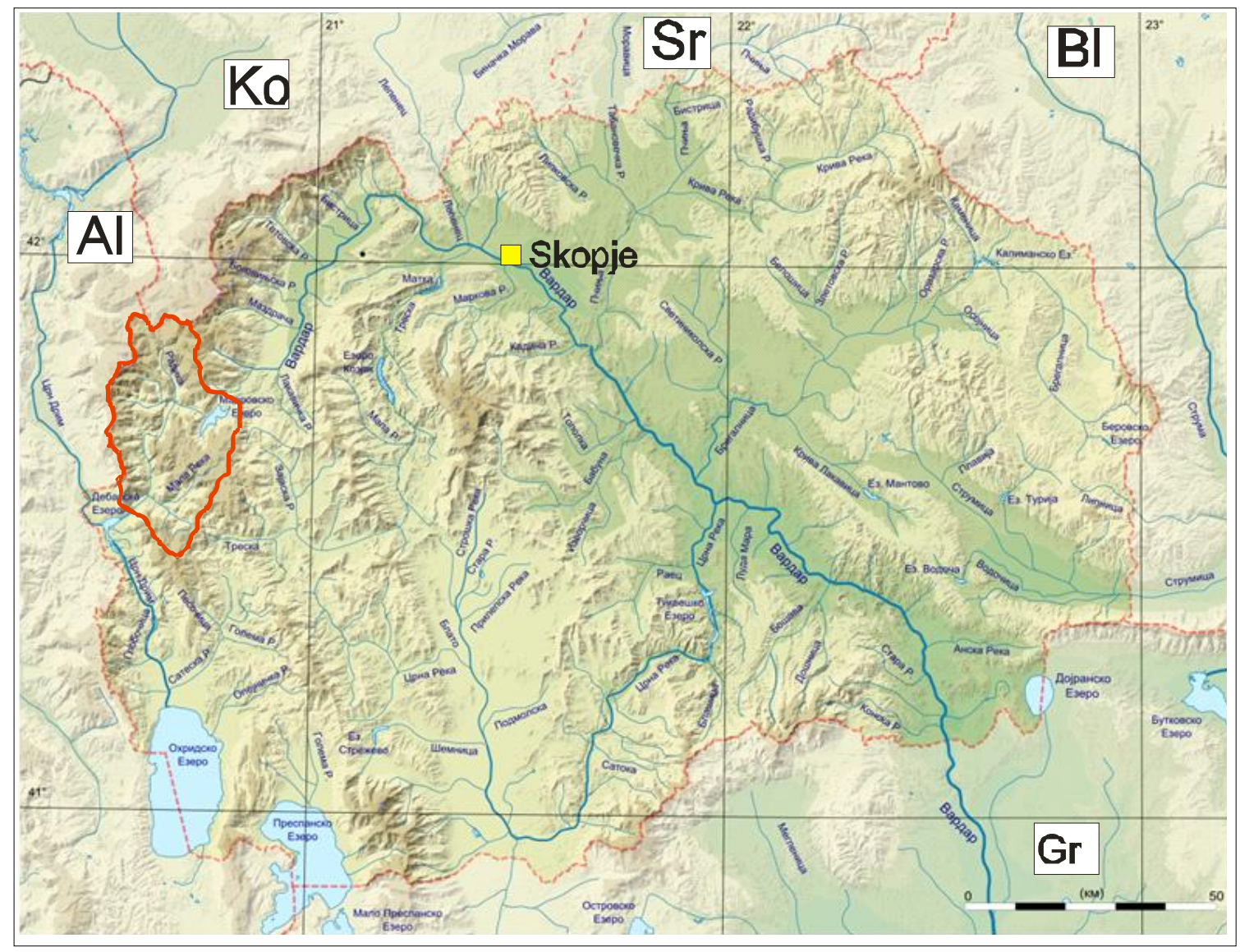

Fig. 2 The position of Radika River and its catchment area in the Republic of Macedonia 


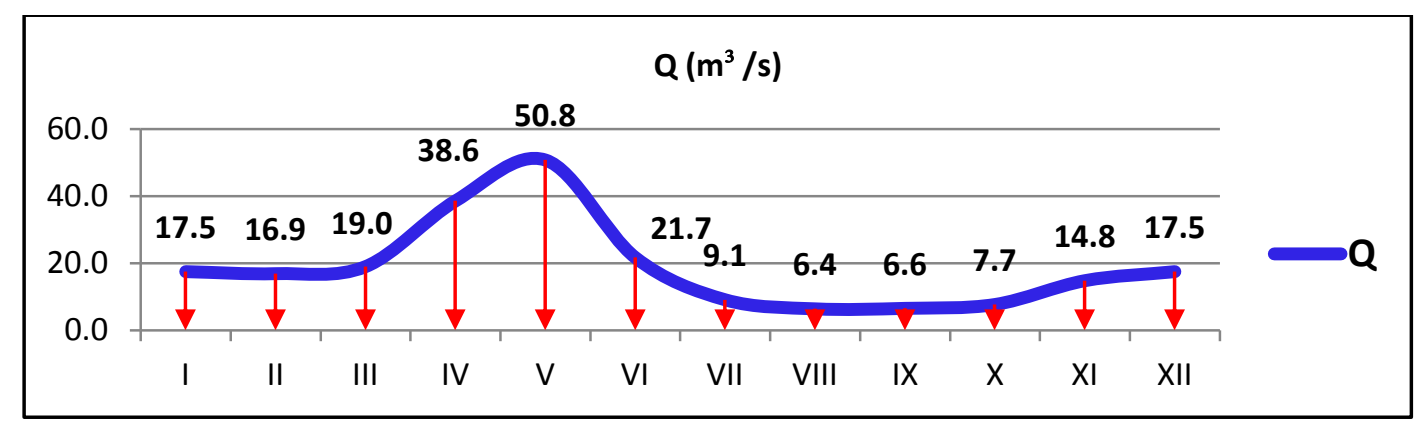

Fig. 3 Average annual river outflow at sample point Boskov Most (in $\mathrm{m}^{3} / \mathrm{s}$ )

\section{METHODS AND MATERIALS}

In aim of objective detection of water polllution of the Radika River, during 2015 was comprehensively chosen the measuring point Boskov Most, in the lower part of the basin, for the assessment of the quality of which the monitoring was carried out with the frequency of the analyzed samples once a month, except in January due to low temperatures and occurrence of frost. The samplings were in compliance to the ISO 5667. Water samples were collected in polyethylene bottles previously washed withhydrochloric acid and rinsed out with abundan-distilled water in the laboratory and with abundant river water before collection. Eventually on the field, temperature, $\mathrm{pH}$, conductivity, DO and saturation were measured with WTW Multi 340I set. Alkalinity was determined by titration; oxygen fixation was made immediately and measured by Winklermethod, BOD5 and COD by $\mathrm{KMnO}_{4}$. Other paramets were analyzed in the laboratory of the Hydrometeorological Service. Nutrients were determined by spectrophotometryusing UV-VIS Varian Carry 100. Heavy metals concentration of Fe, $\mathrm{Mn}, \mathrm{Pb}, \mathrm{Cd}, \mathrm{Zn}, \mathrm{Cr}$, were determined by atomic absorption spectrometry using Varian 220 by graphite furnace and flame technique. As methods for determination of these parameters were used methods recommended by Standard Methods for the Examination of Water and Wastewater APHA, EPA, and EN/ISO methods. Water quality assessment was based on Macedonian regulation for classification of water quality. According to the Macedonian regulation [3] water is classified in five classes, from very good (class 1) to very bad (class 5). The mapping of the surveyed area was carried out using the Surfer 8 and Corel Draw X3 packages based on a topographic map, scale 1: 200000.

\section{RESULTS AND DISCUSSION}

In the group of indicators of the basic physical and chemical analysis, 10 parameters were taken into account: colour (Pt-Co Units), turbidity (NTU), $\mathrm{pH}$, suspended particulars, ammonia $\left(\mathrm{NH} 4^{+}\right)$, nitrates $\left(\mathrm{NO}^{-}\right)$, nitrites $\left(\mathrm{NO}^{-}\right)$, dissolved oxygen $\left(\mathrm{O}_{2}\right)$, biochemical oxygen demand (BOD) and chemical oxygen demand (COD) from $\mathrm{KMnO}_{4}$. Among the cations, the object of analysis was four alkaline and alkaline earth metals ( $\mathrm{Na}, \mathrm{K}, \mathrm{Ca}$, and $\mathrm{Mg}$ ) and six heavy metals ( $\mathrm{Fe}, \mathrm{Mn}, \mathrm{Pb}, \mathrm{Zn}, \mathrm{Cd}$, and $\mathrm{Cr}$ ).

TABLE 1. BASIC PHYSICAL-CHEMICAL ANALYSIS OF THE WATERS OF RADIKA RIVER AT BOSKOV MOST, EXPRESSED IN MG/L, EXEPT (*)

\begin{tabular}{|c|c|c|c|c|c|c|c|c|c|c|}
\hline \multicolumn{11}{|c|}{ PARAMETERS } \\
\hline Month & $\begin{array}{c}\text { Colour } \\
(\text { Pt-Co)* }\end{array}$ & $\begin{array}{c}\text { Turbidity } \\
\text { (NTU)* }\end{array}$ & $\mathbf{p H} *$ & $\begin{array}{l}\text { Susp. } \\
\text { part. }\end{array}$ & $\underset{\left(\mathrm{NH}_{4}{ }^{+}\right)}{\operatorname{Ammonia}}$ & $\mathrm{NO}_{3}^{-}$ & $\mathrm{NO}_{2}^{-}$ & $\mathbf{O}_{2}$ & BOD & COD \\
\hline feb./15 & 1,80 & 2,00 & 7,73 & 3,00 & 0,00 & 0,19 & 0,00 & 13,22 & 5,37 & 0,81 \\
\hline mar./15 & 2,80 & 6,00 & 7,83 & 7,00 & 0,00 & 0,19 & 0,00 & 7,03 & 1,37 & 1,42 \\
\hline apr./15 & 5,10 & 14,00 & 7,55 & 15,00 & 0,00 & 0,16 & 0,00 & 11,38 & 1,80 & 1,68 \\
\hline may/15 & 3,10 & 11,00 & 7,68 & 12,00 & 0,02 & 0,20 & 0,00 & 10,76 & 2,32 & 1,33 \\
\hline jun./15 & 2,20 & 8,00 & 7,77 & 10,00 & 0,01 & 0,12 & 0,01 & 10,60 & 2,41 & 0,90 \\
\hline jul./15 & 1,20 & 2,00 & 7,92 & 3,00 & 0,01 & 0,08 & 0,01 & 10,66 & 2,47 & 0,89 \\
\hline aug./15 & 1,30 & 4,00 & 7,93 & 5,00 & 0,02 & 0,18 & 0,00 & 12,11 & 3,67 & 0,88 \\
\hline sep./15 & 3,00 & 3,00 & 8,18 & 4,00 & 0,02 & 0,09 & 0,00 & 13,04 & 2,63 & 0,78 \\
\hline oct./15 & 1,10 & 4,00 & 7,72 & 5,00 & 0,04 & 0,16 & 0,00 & 10,91 & 1,71 & 0,80 \\
\hline noe./15 & 1,10 & 4,00 & 7,67 & 5,00 & 0,00 & 0,14 & 0,00 & 11,42 & 1,77 & 1,05 \\
\hline dec./15 & 1,60 & 2,00 & 7,91 & 3,00 & 0,01 & 0,15 & 0,01 & 11,55 & 1,79 & 0,88 \\
\hline$\sum$ (avg.) & 2,21 & 5,45 & 7,81 & 6,55 & 0,01 & 0,15 & 0,01 & 11,15 & 2,48 & 1,04 \\
\hline
\end{tabular}


TABLE 2. THE MAIN CATIONS OF THE HARDNESS IN THE WATERS OF RADIKA RIVER AT BOSKOV MOST (In mg/l)

\begin{tabular}{ccccc}
\hline \multirow{2}{*}{ Month } & \multicolumn{4}{c}{ PARAMETERS } \\
\cline { 2 - 5 } & $\mathbf{C a}^{\mathbf{2}^{+}}$ & $\mathbf{M g}^{\mathbf{+}^{+}}$ & $\mathbf{N a}^{+}$ & $\mathbf{K}^{+}$ \\
\hline feb./15 & 58,06 & 9,09 & 2,65 & 0,91 \\
\hline mar./15 & 46,24 & 8,18 & 3,12 & 0,93 \\
\hline apr./15 & 35,80 & 6,50 & 2,24 & 0,77 \\
\hline may/15 & 34,68 & 9,35 & 3,73 & 1,23 \\
\hline jun./15 & 38,72 & 8,10 & 0,88 \\
\hline jul./15 & 49,12 & 7,16 & 0,69 \\
\hline aug./15 & 29,48 & 3,76 & 3,37 & 0,74 \\
\hline sep./15 & 56,98 & 5,96 & 3,63 & 3,00 \\
\hline oct./15 & 49,14 & 9,54 & 3,23 & 1,76 \\
\hline noe./15 & 47,17 & 4,75 & 6,44 & 0,71 \\
\hline dec./15 & 51,09 & 14,30 & 6,09 & $\mathbf{1 , 2 6}$
\end{tabular}

TABLE 3. CONCENTRATION OF SOME HEAVY METALS IN THE WATERS OF RADIKA RIVER AT BOSKOV MOST (In $\mu \mathrm{g} / \mathrm{l})$

\begin{tabular}{|c|c|c|c|c|c|c|}
\hline \multicolumn{7}{|c|}{ PARAMETERS } \\
\hline Month & $\mathbf{F e}$ & Mn & $\mathbf{P b}$ & Zn & Cd & $\mathrm{Cr}$ \\
\hline feb./15 & 7,0 & 16,0 & 0,15 & 3,50 & 0,08 & 1,10 \\
\hline mar./15 & 13,0 & 7,0 & 1,00 & 0,22 & 0,07 & 0,63 \\
\hline apr./15 & 17,0 & 1,6 & 0,92 & 0,70 & 0,01 & 0,67 \\
\hline may/15 & 5,5 & 1,6 & 0,61 & 1,30 & 0,01 & 0,72 \\
\hline jun./15 & 5,2 & 1,5 & 0,70 & 0,55 & 0,02 & 0,40 \\
\hline jul./15 & 6,0 & 1,6 & 0,08 & 0,22 & 0,05 & 0,00 \\
\hline aug./15 & 24,0 & 1,6 & 0,72 & 0,22 & 0,04 & 0,00 \\
\hline sep./15 & 2,5 & 4,0 & 0,44 & 1,80 & 0,03 & 0,49 \\
\hline oct./15 & 6,0 & 6,0 & 0,97 & 4,20 & 0,17 & 0,70 \\
\hline noe./15 & 16,0 & 1,6 & 0,94 & 1,60 & 0,12 & 0,04 \\
\hline dec./15 & 16,0 & 1,6 & 0,44 & 5,80 & 0,06 & 0,07 \\
\hline$\sum$ (avg.) & 10,7 & 4,0 & 0,63 & 1,83 & 0,06 & 0,44 \\
\hline
\end{tabular}

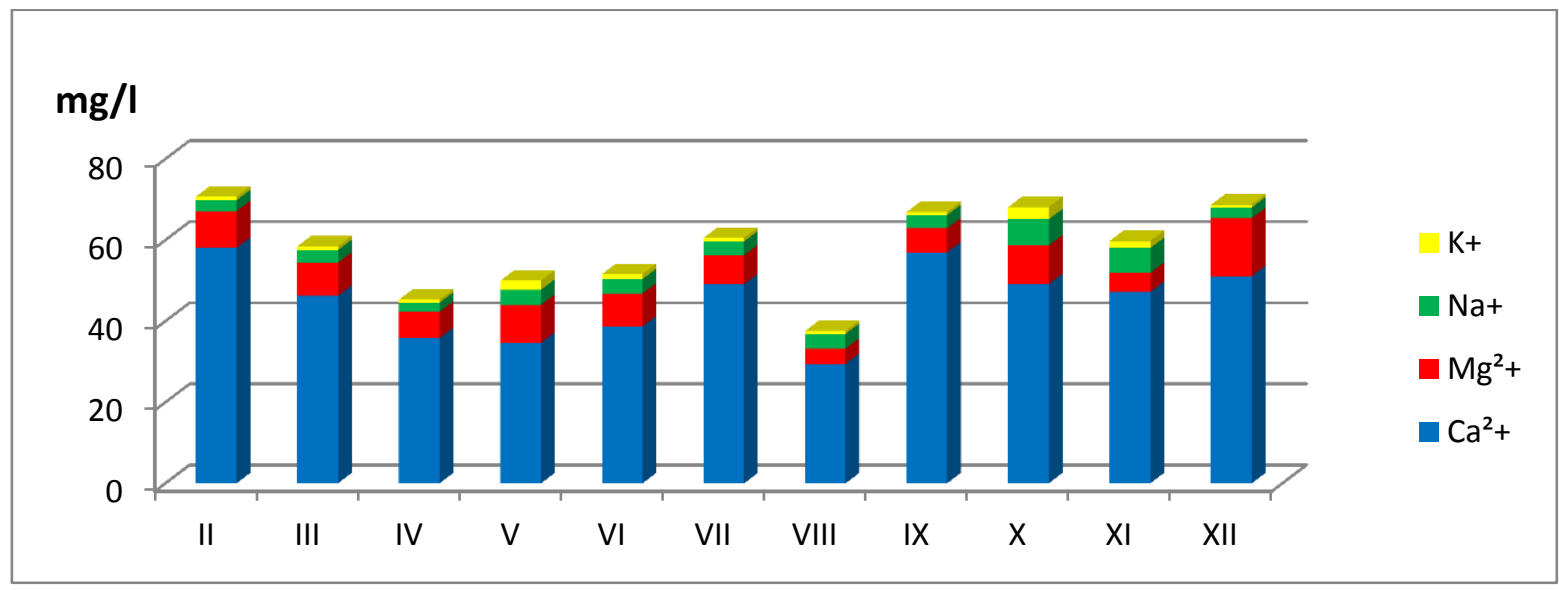

Fig. 4 Annual regime of concentration of some cations in the waters of Radika River at Boskov Most (mg/l) $-4-$ 


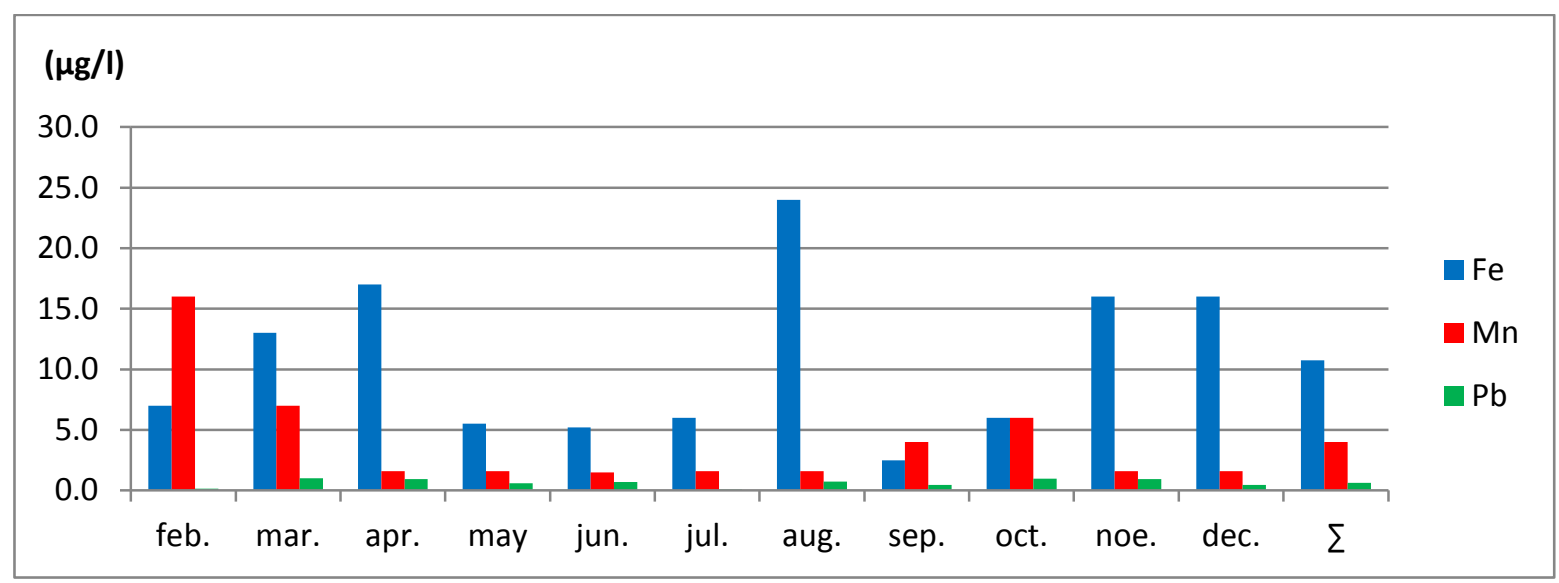

Fig. 5 Annual regime of concentration of some heavy metals in the waters of Radika River at Boskov Most ( $\mu \mathrm{g} / \mathrm{l})$

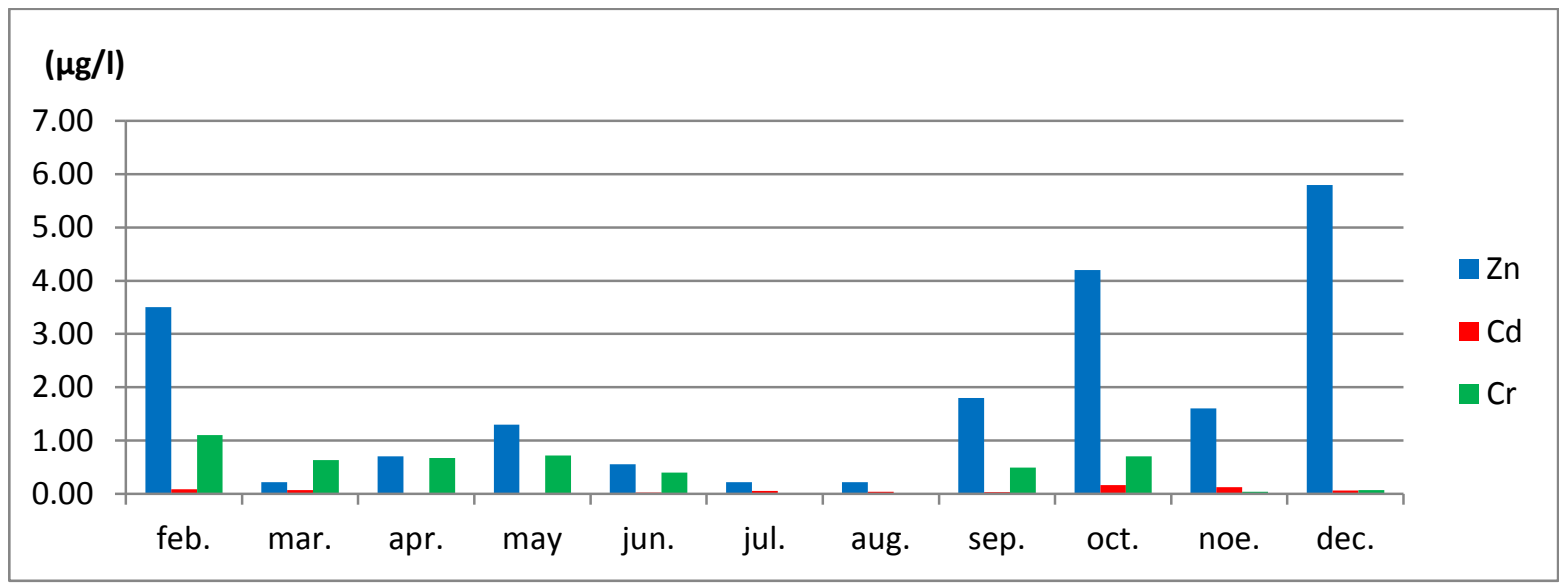

Fig. 6 Annual regime of concentration of some heavy metals in the waters of Radika River at Boskov Most ( $\mu \mathrm{g} / \mathrm{l})$

The color as an indicator in the waters of the Radika River in the investigated period constantly shows the values for quality of class I (Table 1).

The turbidity as a form of mechanical water pollution permanently demonstrates the values appropriate for the quality of class V of the Radika River (Table 1).

The acidity $(\mathrm{pH})$ of all samples during the whole surveillance corresponded to Class I quality (Table 1). The optimum $\mathrm{pH}$ range of the exponent in the rivers ranges from 6.5-8.0 [4]. The low $\mathrm{pH}$ value of the $\mathrm{pH}$ exponent, ie the increased acidity, causes the dissolution of toxic metals and a fatal threat to the organic life [5], which in the case of the Radika River was not observed in any sample.

Suspended particulars as an indicator of mineralization are usually the result of natural erosion processes. Regarding this indicator, it can be concluded that the Radika River at the measuring point Boshkov Most shows Class I quality with an average of $6.55 \mathrm{mg} / \mathrm{l}$. Certain deterioration in the quality of class II in the months of April, May and June is evident, which corresponds to the increased flow of water in the same period (Fig. 3).

Among the forms of nitrogen as a nutrient, ammonium ion $\left(\mathrm{NH}_{4}^{+}\right)$is a toxic and unstable form whose increased concentrations reflect the load of aqueous ecosystems with faecal waters, especially if the amount of dissolved oxygen is low. At the measuring point at Boskov Most it references quality concentrations of class III (average $0.01 \mathrm{mg} / \mathrm{l}$ ). The influence of the faecal waters from the settlements on the Radika River waters is especially noticeable in the warm months of the year when the water flow has been drastically reduced and the concentration of the pollutant is increased (Table 1).

The input of nitrates $\left(\mathrm{NO}_{3}{ }^{-}\right)$as a form of nitrogen in the river water takes place through the disposal of animal waste, faeces and rinsing of soils treated with fertilizers [6]. The concentration of nitrates in the Radika River during the examined period with an average of $0.15 \mathrm{mg} / \mathrm{l}$ is maintained within the quality class of class I-II (Table 1) and excludes assumed factors as a source of contamination. Nitrite $\left(\mathrm{NO}_{2}{ }^{-}\right)$is an intermediate product between ammonia and nitrates. Nitrite is a toxic form of

$$
-5 \text { - }
$$


nitrogen for wildlife in the waters and at very low concentrations. In the waters of Radika, the average annual concentrations of $0.01 \mathrm{mg} / \mathrm{l}$ which were corresponding to class III-IV quality were observed and undoubtedly included an anthropogenic factor for their input through wastewater, agricultural and industrial activities. Increased concentrations occur in the months with lower flow (Table 1).

Among the forms of oxygen regime, as subject of analysis were conducted: dissolved oxygen (DO), biochemical oxygen demand (BOD) and chemical oxygen demand (COD). Dissolved oxygen is an indicator of "health" of the water ecosystem and metabolic processes related to the degradation of existing organic matter [7]. According to this indicator, the Radika River near Boskov Most expresses high quality (class I) with an average annual concentration of $11.15 \mathrm{mg} / \mathrm{l}$ (Table 1). Moreover, the anthropogenic impact on the quality of Radica's water is evident through the biochemical oxygen demand (BOD) that indicates the presence of organic matter for whose dissolution is consumed dissolved oxygen. At the measuring point at Boskov Most, with a concentration of $2.48 \mathrm{mg} / \mathrm{l}$, the Radika River is characterized by an average annual Class II quality and seasonal culmination during decreased flow in the summer months (Table 1). The chemical oxygen demand (COD) through $\mathrm{KMnO}_{4}$ is an indicator that reflects oxygen consumption for total breakdown and oxidation processes from the present metals in the water. Deterioration of the water quality is not visible at all with an average concentration of $1.04 \mathrm{mg} / \mathrm{l}$, and therefore the involvement of the anthropogenic factor (Table 1) is also excluded.

Between the cations that express the total water hardness subject to check have been: sodium, potassium, calcium and magnesium. A high annual calcium concentration of $45 \mathrm{mg} / \mathrm{l}$ is striking (Table 2, Fig. 4). It exceeds the average concentrations of European rivers of $31.7 \mathrm{mg} / \mathrm{l}$ and averages for unpolluted rivers of $24.2 \mathrm{mg} / \mathrm{l}$ [8]. This also raises doubts about possible anthropogenic pollution of the Radika River whose clues were not confirmed by field research. Only the initial assumptions about the high concentration of this cation were confirmed, given that it is lightly reactive and originates from carbonate rocks (limestone and gypsum) that are widely represented in the drainage basin of the Radika River. In other cations annual concentrations are below the average of European and polluted rivers [8]. Their annual regime is inversely proportional to the annual flow (Table 2, Figs. 3, 4).

Regarding the heavy metal water load of the Radika River, the main objective was to detect possible anthropogenic impacts, considering that in general, the metal concentrations in natural waters are very low due to their low solubility in the aquatic environment [9]. On the other hand, surface water hydrochemistry depends on several natural factors such as intensity and composition of rain water, chemical reactions between water and soil or sediment, biochemical reaction, and surface watergroundwater interactions, as well as on human activities [10].

Iron is one of the most widespread metals in the lithosphere and in the surface waters [11]. In the case of the Radika River waters at the measuring point Boskov Most, the average concentrations over the monitoring corresponded to Class I-II (10.7 $\mu \mathrm{g} / \mathrm{l})$ quality without seasonal or monthly excess (Table 3, Fig. 5). Consequently, highest concentrations were observed in August when the flow of the watercourse was lowest.

Manganese in the waters naturally originates most from the dissolution of shales and sandstones, as well as through metallurgical activities [12]. It reduces photosynthesis in plants by reducing the absorption of sunlight. At the measuring point Boshkov Most in the water of the Radika River, the average annual concentration (4.0 $\mu \mathrm{g} / \mathrm{l})$ according to the national classification regulation ranges within class I-II without any monthly excess (Table 3, Fig. 5).

Lead is a heavy metal that can be embedded in rivers through mining and industrial waste from factories for: military means, accumulators, batteries, etc. [13]. The correctness of the water of the Radika River near Boskov Most is quite clear according to the average values in the investigated period $(0.63 \mu \mathrm{g} / \mathrm{l})$ where the water quality in the class I-II with constant monthly distribution is maintained (Table 3, Fig. 5).

Zinc is an essential element for plants and animals as it is necessary for the functioning of certain enzymes. Notwithstanding, Zinc is relatively non-toxic to terrestrial organisms. It is acutely and chronically toxic to aquatic organisms, particularly fish. Zinc toxicity decreases with increasing hardness, increases with increasing temperature, and increases with decreasing dissolved oxygen. If it is known that in the unpolluted waters its concentration does not exceed $5 \mu \mathrm{g} / \mathrm{l}$, then the anthropogenic impact on the water of the Radika River is negligible and consistently referenced for class I-II quality with an average of $1.83 \mu \mathrm{g} / \mathrm{l}$. Moreover, monthly variations show higher concentrations during winter months (Table 3, Fig. 6).

Cadmium is a toxic metal that in nature is very rare. In some rivers in the Republic of Macedonia it is naturally present with the origin of some Paleozoic and Mesozoic rocks [14]. The human factor introduces cadmium in the waters through cement dust, melting of zinc ores, production of batteries, and other, which is not present in the drainage of Radika as a possible source of pollution. Such pollutant sources are not represented in the catchment area which is largely part of a national park. The presence of cadmium in the waters of Radika during the examined period shows average values for quality of class III $(0,06 \mu \mathrm{g} / \mathrm{l})$. The mild increase in its concentration in the months of November and December to the level of class III-IV is a consequence of natural hydro-geochemical processes (Table 3, Fig. 6).

Chromium is a heavy metal, naturally occurring in the chromite ore $\left(\mathrm{FeCr}^{2} \mathrm{O}^{4}\right)$. The content of its toxic form in the hexavalent state $\left(\mathrm{Cr}^{6+}\right)$ in the waters of Radika during the examined period with average $0.44 \mu \mathrm{g} / \mathrm{l}$ consistently refers to the

$$
-6-
$$


concentration of quality class I-II (Table 3; Fig. 6). Its concentration is slightly increased only in the case of use for agricultural purposes where it should not exceed $0.1 \mu \mathrm{g} / 1$ for a longer period [15].

\section{CONCLUSION}

Subject of study in this paper were the waters of the Radika River in the Mavrovo National Park monitored in the lower part of the basin, before the inflow into Debar Lake at the measuring point Boshkov Most in the period February-December, 2015 (sample point, Fig. 1). The assessment of the quality of the waters of the Radika River was based on 10 parameters of the basic physical and chemical analysis, 4 cations and 6 heavy metals as a quality criterion. Regarding the basic physical and chemical analysis, deterioration of the water quality in relation to 6 parameters was determined. Among them, defects were found to permanently exceed the permitted values, often (in ammonium ion and biochemical oxygen demand) and occasionally (suspended particles, nitrites and dissolved oxygen). The best water quality was observed in terms of color, pH exponent, nitrates and chemical oxygen demand (Class I). The weakest water quality was registered in terms of turbidity (class V), ammonium ion and nitrite (class III-V) and BOD (class II), which undoubtedly highlights the organic burden on the waters of the Radika River from anthropogenic sources of pollution, primarily by input of faecal waters from rural households, catering facilities and livestock breeding, as well as from the use of chemical preparations in agricultural production, which is poorly developed in the catchment area. The seasonal fluctuation of concentrations is consistent with seasonal fluctuations in river flow. In the cations expressing the hardness of the water, a slight increase in calcium is evident, reflecting the easily soluble carbonate rocks from the geological base in the basin. Regarding the presence of heavy metals in the waters of the Radika River, only incidental deterioration of the water quality on the basis of cadmium was determined, which occasionally expresses concentrations within the class III-IV. The annual regime of heavy metals in the waters is not a reflection of anthropogenic, industrial pollution and is averagely represented in concentrations suitable for class I-II quality and does not correspond with the annual regime of river flow. The total water quality of the Radika River during the survey period justifies the status, the expectations and the needs of the protected water flow in the protected zone.

\section{ACKNOWLEDGMENT}

We owe a special gratitude to the Hydrometeorological Service of the Republic of Macedonia due to the technical logistics, especially in obtaining data for the annual river regime.

\section{REFERENCES}

[1] D. Vasileski, "Radika-Hydrologically-hydrographical study," PhD thesis, Faculty of Natural Sciences and Mathematics, Skopje, p. 264, 1990. (In Macedonian)

[2] N. Panov, "The National Parks since complex touristical motives," Geographical Reviews, vol. 32-33, pp. 121-133, 1998. (In Macedonian with English summary)

[3] Statute for water classification in the Republic of Macedonia, Official Gazette of Republic of Macedonia, No. 18/99, pp. 1165-1173. (In Macedonian).

[4] K. Addy, L. Green, and Herron E., Ph and Alkality, Kingston, Rhode Island, URI WATERSHED WATCH, 2004

[5] S. Ramani, R. Bojkovska, and K. Pavlov, "Environmental Assessment of Water quality of the River Strumica During the last ten years with Overview on 2008," Ohrid, Balwoise Proceedings, 2010

[6] P.G. Conrad, , D.I. Carey, J.S. Webb, J.S. Dinger, and M.J. McCourt, “Ground-water quality in Kentucky: Nitrate-nitrogen,” Kentucky Geological Survey, ser. 11, Information Circular 60, 4 p, 1999

[7] K. Pavlov, "The Influence of Natural and Antropogenal Factors on Water Pollution in Tikveš Basin," PhD thesis, Faculty of Natural Sciences and Mathematics, Skopje, p. 424, 2011. (In Macedonian)

[8] J.V. Walther, Essential of Geochemistry, Sudbury: Jones and Barlett Publishers, 2005

[9] L. Chen, X. Xu, J. Huang, and J. Liang, "Environmental Effects of Heavy Metals in Xiangsi River of Tongling, China," International Journal of Environmental Protection, vol. 1 pp. 30-35, 2012

[10] M. S. Samsudin, H. Juahir., S. M. Zain, and N. H. Adnan, "Surface River Water Quality Interpretation Using Environmetric Techniques: Case Study at Perlis River Basin, Malaysia," International Journal of Environmental Protection, vol.1, pp. 1-8, 2011

[11] V. Karri-Matti, "Direct and indirect effects of iron on river ecosystems," Ann. Zool. Fennici, Vol. 32, Pp. 317-329, 1995

[12] S. Popov, T. Stafilov, R. Šajn, C. Tănăselia, and K. Bačeva, "Applying of Factor Analyses for Determination of Trace Elements Distribution in Water from River Vardar and Its Tributaries, Macedonia/Greece," The Scientific World Journal, Article ID 809253, 2014. DOI: http://dx.doi.org/10.1155/2014/809253

[13] G. R. Smith, Lead Recycling in the United States, Flow studies for recycling in the United States, 1998

[14] K. Pavlov, K. Bačeva, T. Stafilov, D. Vasileski, and S. Toševska, "Assessment of Toxic Metal Pollution in Some Rivers in the Tikveš Basin, Republic of Macedonia," International Journal of Environmental Protection, vol. 2, pp. 9-16, Dec. 2012.

[15] D.R. Rowe and I.M. Abdel-Mazid, Handbook of Wastewater Reclamation and Reuse, U.S.A.: CRC Press, Inc. p. 550,1995 